\title{
Analysing students' attitudes towards the learning of specialized software
}

\author{
Cristina S. Rodrigues \\ Algoritmi Reasearch Centre \\ University of Minho \\ Braga, Portugal \\ crodrigues@dps.uminho.pt
}

\author{
Ana Maria A. C. Rocha \\ Algoritmi Reasearch Centre \\ University of Minho \\ Braga, Portugal \\ arocha@dps.uminho.pt
}

\begin{abstract}
In this article the situation of teaching in engineering courses using specialized software support is evaluated and analysed. The statistics courses in engineering often come off as element of formal exposure to statistical analysis and research methods. The software support during classes intends to facilitate and reinforce learning with computational resolution of statistical specific problems. We report a research that investigates students' attitudes towards computers and their effect on statistics unit performance. The preliminary results of research using a small sample of 47 students enrolled in the experimental statistics unit of the 1st year of the master's degree in industrial engineering from the University of Minho indicate that software perceived usefulness has a positive effect on student success, although perceived ease of use and perceived self-performance do not influence.
\end{abstract}

Keywords-students' attitudes; statistical sofwtare; usefulness; ease of use; self-performance

\section{INTRODUCTION}

Over the past 100 years engineering has evolved to mathematical modelling and scientific analysis [3]. According to these authors, the change in the U.S. for al teaching with more math and science was the result of immigration to U.S. of European engineers and teachers who introduced European approaches to engineering education. Another important change is the influence of information, communication and computer technologies in the engineering education, citing as example the MIT that combines different technologies in its Technology Enhance Active Learning (TEAL). In terms of computational technologies, the calculator machine still remains but the computer has progressively increased its impact in education "Spreadsheets and equation solving programs such as MATLAB are probably the most common uses of the computer in engineering education" ([3], p1353).

The teaching of quantitative materials has evolved with the help of specific software. Courses in quantitative analysis, such as statistics and numerical methods, are important to engineering students, since they allow the formal exposure to calculus techniques and analyses that are important for their future career. In particular, they allow to integrate concepts, planning and facilitate analysis and to reduce analysis time.

The importance of statistics, recognized by those who teach [6] and the knowledge of statistics are important in most professions. However, students often struggle with the difficulty of the issues, so it is important that teachers find ways to help their students learn and better understand the statistical topics [1]. To benefit students in the learning process, the use of computer technologies is an important resource to integrate technology in teaching [2]. Given the computer as a major tool, there is a growing interest in how students interact with computers and how it impact on the learning process (see for instance [5]).

The objective of our research is to assess engineering students' overall attitudes towards computers. In particular, it is intended to explore the factors that may influence success in engineering courses in disciplines with learning support computational software, like statistics curricular units.

The next sections present and discuss the preliminary results obtained with a study performed in the experimental statistics unit of the 1st year of the master's degree in industrial engineering from the University of Minho.

\section{METHODOLOGY}

Since engineering requires analytical skills, most engineering courses include a statistics curricular unit as part of the core curriculum. At the University of Minho, in Portugal, the Department of Production and Systems Engineering has teachers with specialized skills that provide and teach classes in applied statistical and numerical methods to engineering courses. In the specific case of the statistical classes, classes are usually organized in theoretical exposition of program topics and in solving practical exercises with the support of a calculator machine. The MSc in Industrial Engineering has a half-semester unit named experimental statistics with a typology of classes adapted to theoretical and laboratory classes. In the theoretical classes, topics are exposed and explained followed by exercises (using the calculator) to consolidate knowledge. On the other hand, the laboratory classes are taught in computer labs where the use of specialized software (in this case IBM $®$ SPSS® Statistics 21 [7]) is explored for solving practical exercises.

The study presented in this paper intends to analyses MSc in Industrial Engineering students' perspectives about the learning and use of statistical software during experimental statistics classes. In this direction, we plan to explore the effect of the variables of perceived computer usefulness, perceived ease of use and perceived selfperformance on student's success. The success was 
measured using the final grade obtained in the practical examination of the software.

Data was obtained through questionnaires administered to students enrolled in the Experimental Statistics unit of the MSc in Industrial Engineering, who filled the questionnaire at the end of the required 8-week-long applied statistics classes.

Besides characterization information such as gender and age, questionnaires also collected specific information about students: first time attending the course of applied statistics (yes/ no answers - latter coding the "yes" answers as 1-yes; otherwise 0-no.); Master academic degree previously completed; average grade of the previous academic degree completed and course area (coding as 1-sciences or engineering; otherwise $0-$ no).

A total of 47 usable questionnaires were returned and used for the data analysis. Table summarizes sample profile. $53.2 \%$ of respondents were male and $46.8 \%$ female. The ages varies from 21 minimum to 37 years maximum, with a mean age of 24.4 years $(\mathrm{sd}=4.206)$.

Questionnaires included two questions related to respondents' perspective about the statistical software used during classes: the perceived usefulness and the perceived ease of use. Both scales were adapted from the previous work of [4] and used five-point Likert type scale, anchored by 1-"strongly disagree" to 5-"strongly agree". The authors also included a new question intended to assess how students rate their own performance with the statistical software (on a scale of 1 (minimum) to $10(\max ))$ in terms of: autonomy; knowledge of the menus and procedures and knowledge of statistical interpretation of outputs results.
TABLE I. - SAMPLE PROFILE

\begin{tabular}{|l|c|c|}
\hline Respondents' Profile & $\begin{array}{c}\text { Response } \\
\text { Count }\end{array}$ & $\begin{array}{c}\text { Response } \\
\text { Frequency } \\
(\%)\end{array}$ \\
\hline Gender & 25 & $53.20 \%$ \\
\hline Male & 22 & $46.80 \%$ \\
\hline Female & 39 & $83.00 \%$ \\
\hline Fist time attendant & 8 & $17.00 \%$ \\
\hline Yes & 25 & $53.20 \%$ \\
\hline No & 22 & $46.80 \%$ \\
\hline Previous course area & 5 & $10.60 \%$ \\
\hline Sciences or Engineering & 41 & $87.20 \%$ \\
\hline Other & 1 & $2.10 \%$ \\
\hline Previous course & 26 & $55.30 \%$ \\
\hline Pre-Bologna graduation & 10 & $21.30 \%$ \\
\hline After Bologna graduation & 11 & $23.40 \%$ \\
\hline After Bologna integrated master \\
\hline Age & \\
\hline Age less than or equal to 22 years & \\
\hline Age between 23 and 25 years & \\
\hline Age greater than or equal to 26 years & 11 \\
\hline
\end{tabular}

TABLE II. - SCALE RELIABILITY

\begin{tabular}{|c|c|c|c|c|c|}
\hline Items & $\begin{array}{l}\text { Corrected Item- } \\
\text { Total Correlation }\end{array}$ & $\begin{array}{l}\text { Cronbach's } \\
\text { alpha }\end{array}$ & $\begin{array}{l}\text { Factor } \\
\text { Loading }\end{array}$ & $\begin{array}{r}\text { Variance } \\
\text { explained }\end{array}$ & $\begin{array}{l}\text { \# of } \\
\text { factors }\end{array}$ \\
\hline Perceived software usefulness & & 0.856 & & $64.56 \%$ & 1 \\
\hline $\begin{array}{l}\text { 1. Using a statistical package such as SPSS can improve my job } \\
\text { performance }\end{array}$ & 0.699 & & 0.822 & & \\
\hline $\begin{array}{l}\text { 2. Using a statistical package such as SPSS can make it easier to do } \\
\text { my job }\end{array}$ & 0.764 & & 0.867 & & \\
\hline $\begin{array}{l}\text { 3. Using a statistical package such as SPSS in my job can increase } \\
\text { my productivity }\end{array}$ & 0.752 & & 0.856 & & \\
\hline 4. I find a statistical package such as SPSS useful in my job & 0.801 & & 0.889 & & \\
\hline $\begin{array}{l}\text { 5. Using a statistical package such as SPSS would enable me to } \\
\text { Accomplish statistical analysis more quickly }\end{array}$ & 0.398 & & 0.527 & & \\
\hline Perceived ease of use & & 0.776 & & $60.12 \%$ & 1 \\
\hline 1. I find it easy to get SPSS to do what I want it to do & 0.643 & & 0.826 & & \\
\hline 2. My interaction with SPSS is understandable and clear & 0.618 & & 0.814 & & \\
\hline 3. I find SPSS to be flexible to interact with & 0.624 & & 0.806 & & \\
\hline 4. It is easy for me to become skilful at using SPSS & 0.439 & & 0.640 & & \\
\hline Perceived performance & & 0.931 & & $88.16 \%$ & 1 \\
\hline 1. Autonomy & 0.864 & & 0.940 & & \\
\hline 2. Knowledge of the menus and procedures & 0.894 & & 0.956 & & \\
\hline 3. Knowledge of statistical interpretation of outputs results & 0.827 & & 0.920 & & \\
\hline
\end{tabular}




\section{RESULTS AND DISCUSSION}

\section{A. Scale reliability}

The analysis initiate with scales reliability and unidimensionality using Cronbach's alpha, item-to-total correlation and exploratory factor analysis. Reliability results were summarized in Table II.

After reliability analysis, scales were transformed as a mean indicator of the items (all items were retained).

\section{B. Results}

The research intends to determine if it's possible to predict students' grades considering as independent variables: perceived software usefulness, perceived ease of use, perceived self-performance and the average grade of the previous academic degree completed. In order to accomplish that, two procedures were used:

1) a linear regression to predict students' grades;

2) a logistic regression to determine the impact of multiple independent variables presented simultaneously to predict students' approval.

Before the analyses, data were screened for the assumptions of parametric statistics and found to be met. The stepwise regression was conducted to find the best combination of predictor of students' grade among the four independent variables. Table III resumes the output for linear regression.

TABLE III. - PREDICTING CURRICULAR UNIT GRADE (STEPWISE METHOD)

\begin{tabular}{|c|c|c|c|c|c|}
\hline \multicolumn{6}{|c|}{ Coefficients $^{\mathrm{a}}$} \\
\hline \multirow{2}{*}{ Model } & \multicolumn{2}{|c|}{$\begin{array}{c}\text { Unstandardized } \\
\text { Coefficients }\end{array}$} & \multirow{2}{*}{$\begin{array}{c}\text { Standardized } \\
\text { Coefficients } \\
\text { Beta }\end{array}$} & \multirow[b]{2}{*}{$\mathrm{T}$} & \multirow[b]{2}{*}{ Sig. } \\
\hline & B & $\begin{array}{l}\text { Std. } \\
\text { Error }\end{array}$ & & & \\
\hline 1 (Constant) & -2.535 & 1.839 & & $-1,379$ & 0.175 \\
\hline Usefulness & 1.982 & 0.438 & 0.559 & 4,521 & 0.000 \\
\hline$R$ square & 0.312 & & & & \\
\hline $\begin{array}{l}\text { Adjusted } R \\
\text { square }\end{array}$ & 0.297 & & & & \\
\hline $\begin{array}{l}\text { Std. Error of } \\
\text { the Estimate }\end{array}$ & 1.924 & & & & \\
\hline$F(p$-value $)$ & 20.443 & $(0.0)$ & & & \\
\hline 2 (Constant) & -7.453 & 2.457 & & -3.034 & 0.004 \\
\hline Usefulness & 1.583 & 0.433 & 0.446 & 3.657 & 0.001 \\
\hline $\begin{array}{l}\text { Previous } \\
\text { average } \\
\text { grade }\end{array}$ & 0.490 & 0.175 & 0.341 & 2.794 & 0.008 \\
\hline$R$ square & 0.416 & 0.389 & & & \\
\hline $\begin{array}{l}\text { Adjusted } R \\
\text { square }\end{array}$ & 0.389 & & & & \\
\hline $\begin{array}{l}\text { Std. Error of } \\
\text { the Estimate }\end{array}$ & 1.793 & & & & \\
\hline$F(p$-value $)$ & 15.669 & $(0.0)$ & & & \\
\hline
\end{tabular}

Only two steps were concluded with perceived software usefulness and the average grade of the previous academic degree completed providing the best combination with an Adjusted R Square of $38.9 \%$ and a significant $F=15.669, p<0.01$. Two variables, perceived ease and perceived self-performance, do not appear to be of any importance in determining students' grade.

The logistic regression required a conversion of the students' grade into a new dichotomous variable: 1) less than 5 values (failure); 2) 5 or more values (success).

Table IV presents the results with the constant only model which resulted in an overall correct percentage of $68.1 \%$.

TABLE IV. - THE CLASSIFICATION TABLE IN BLOCK 0

\begin{tabular}{|c|c|c|c|c|c|}
\hline \multicolumn{6}{|c|}{ Classification Table ${ }^{a, b}$} \\
\hline \multirow{3}{*}{\multicolumn{3}{|c|}{ Observed }} & \multicolumn{3}{|c|}{ Predicted } \\
\hline & & & \multicolumn{2}{|c|}{ Approved } & \multirow{2}{*}{$\begin{array}{c}\text { Percentage } \\
\text { Correct }\end{array}$} \\
\hline & & & Failure & Success & \\
\hline \multirow[t]{3}{*}{ Step 0} & \multirow[t]{2}{*}{ Approved } & Failure & 0 & 15 & 0.0 \\
\hline & & Success & 0 & 32 & 100.0 \\
\hline & \multicolumn{2}{|c|}{ Overall Percentage } & & & 68.1 \\
\hline
\end{tabular}

Table $\mathrm{V}$ presents the results when the predictors are included (enter method) which resulted in an overall correct percentage of $74.5 \%$. In this study, $46.7 \%$ were correctly classified for the Failure group and $87.5 \%$ for the Success group.

TABLE V. - THE CLASSIFICATION TABLE (ENTER METHOD)

\begin{tabular}{|c|c|c|c|c|c|}
\hline \multicolumn{6}{|c|}{ Classification Table $^{\mathrm{a}}$} \\
\hline \multirow{3}{*}{\multicolumn{3}{|c|}{ Observed }} & \multicolumn{3}{|c|}{ Predicted } \\
\hline & & & \multicolumn{2}{|c|}{ Approved } & \multirow{2}{*}{$\begin{array}{c}\text { Percentage } \\
\text { Correct }\end{array}$} \\
\hline & & & Failure & Success & \\
\hline \multirow[t]{3}{*}{ Step 1} & \multirow[t]{2}{*}{ Approved } & Failure & 7 & 8 & 46.7 \\
\hline & & Success & 4 & 28 & 87.5 \\
\hline & \multicolumn{2}{|c|}{ Overall Percentage } & & & 74.5 \\
\hline
\end{tabular}

Variable results are presented in Table VI. The Wald criterion demonstrated that only usefulness and previous grade made a significant contribution to prediction $(\mathrm{p}<0.10) . \operatorname{Exp}(B)$ value indicates that when the perceived usefulness is raised by one unit, the odds ratio is 3.438 times as large and therefore students are 3.438 more times likely to be approved at software test. If the previous grade is raised by one unit, the odds ratio is 1.884 times as large.

TABLE VI. - VARIABLES IN THE EQUATION (ENTER METHOD)

\begin{tabular}{|l|r|c|c|c|c|r|}
\hline \multicolumn{7}{|c|}{ Variables in the Equation - Step 1 } \\
\hline & \multicolumn{1}{|c|}{ B } & S.E. & Wald & df & Sig. & Exp(B) \\
\hline Usefulness & 1.235 & 0.699 & 3.124 & 1 & 0.077 & 3.438 \\
\hline Ease & -0.275 & 0.896 & 0.094 & 1 & 0.759 & 0.76 \\
\hline SPSS_Perf & 0.34 & 0.349 & 0.953 & 1 & 0.329 & 1.405 \\
\hline Previous grade & 0.633 & 0.366 & 2.991 & 1 & 0.084 & 1.884 \\
\hline Constant & -13.704 & 5.498 & 6.212 & 1 & 0.013 & 0 \\
\hline
\end{tabular}

a. Variable(s) entered on Step 1: Usefulness, Ease, SPSS_Perf, Previous grade. 


\section{CONCLUSIONS}

This article presents a preliminary study aiming to explore the factors that may influence success in disciplines with learning support computational software. A questionnaire was administrated to students in the experimental statistics curricular unit at the 1 st year of the master's degree in industrial engineering from the University of Minho in order to evaluate students' attitudes towards computers and their effect on statistics unit performance. The preliminary results indicate that software perceived usefulness has a significant effect on students' success highlighting it as a very important condition to overcome students' barriers. Besides, the tests revealed that the perceived ease of use and perceived selfperformance of the students do not influence the approval in the statistics unit.

Since the learning of specialized software can play an important role in the acquisition of analytical skills, these results need to be explored in future. The ongoing research intends to integrate other computing software, should also take into account new factors, such as personality traits, and a comparison between levels of study, for instance undergraduate and postgraduate.

\section{ACKNOWLEDGMENT}

This work has been partially funded by FCT within the Project Pest-OE/EEI/UI0319/2014.

\section{REFERENCES}

[1] N. Baharun and A. Porter, "Removing the angst from statistics," Centre for Statistical and Survey Methodology, University of Wollongong, Working Paper 26-09, 2009, 6p. http://ro.uow.edu.au/cssmwp/46

[2] V. Celik and E. Yesilyurt, "Attitudes to technology, perceived computer self-efficacy and computer anxiety as predictors of computer supported education," Computers \& Education, vol. 60, Issue 1, January 2013, pp. 148-158.

[3] J. E. Froyd, Ph. C. Wankat, and A. K. Smith, "Five major shifts in 100 years of engineering education," Proceedings of the IEEE, IEEE Press, May 13, 2012, vol. 100, pp. 1344-1360, doi:10.1109/JPROC.2012.2190167

[4] M. K. Hsu, S. W. Wang, and K. K. Chiu, "Computer attitude, statistics anxiety and self-efficacy on statistical software adoption behavior: An empirical study of online MBA learners," Computers in Human Behavior, vol. 25, Issue 2, March 2009, pp. 412-420.

[5] S. Korobili, A. Togia, and A. Malliari, "Computer anxiety and attitudes among undergraduate students in Greece", Computers in Human Behavior, vol.26, Issue 3, May 2010, pp. 399-405.

[6] P. A. Schutz, L. M. Drogosz, V. E. White, and C. Distefano, "Prior knowledge, attitude, and strategy use in an introduction to statistics course," Learning and Individual Differences, vol. 10, Issue 4, 1998, pp. 291-308.

[7] IBM Corp. Released 2012. IBM SPSS Statistics for Windows, Version 21.0. Armonk, NY: IBM Corp. 